\title{
POLA ASUH ORANG TUA TERHADAP PRESTASI BELAJAR PADA SISWA KELAS IV SD NEGERI BOTOLAMBAT 03 BATANG
}

\author{
D. Setyo Prabowo ${ }^{1}$, Rofian $^{2}$, Intan Rahmawati ${ }^{3}$ \\ ${ }^{123} J u r u s a n$ Pendidikan Guru Sekolah Dasar, \\ Fakultas IImu Pendidikan Universitas PGRI \\ Semarang, Indonesia \\ e-mail: deniprabowo34@gmail.com ${ }^{1}$, kotakomik.pian@gmail.com² \\ agoesq435@gmail.com ${ }^{3}$
}

\begin{abstract}
Abstrak
Permasalahnya prestasi belajar siswa sangat di pengaruhi oleh pola asuh orangtua yang berbeda-beda dan akan berdampak pada prestasi belajar siswa. Penelitian ini dilakukan bertujuan untuk mengetahui hubungan pola asuh orangtua terhadap prestasi belajar siswa kelas IV SD Negeri Botolambat 03 Batang yang berjumlah 24 siswa dan 24 orangtua siswa yang menjadi sumber penelitian. Metode penelitian ini adalah deskriptif kualitatif. Hasil penelitian menunjukan bahwa kelas IV ada 3 siswa kategori (Sangat Baik), 13 kategori (Baik), 8 kategori (Cukup), dan 0 kategori (Kurang). Prestasi belajar dan pola asuh orangtua memiliki persentase yang berbeda-beda. Pola asuh cenderung Demokratis sebesar 12,5 (sangat baik), 45 (baik), 8,3 (cukup); cenderung Permisif 16 (cukup); cenderung Otoriter 4 (baik), 8,3 (cukup). Bisa disimpulkan bahwa terdapat tiga pola asuh orangtua, pola asuh cenderung demokratis, pola asuh cenderung permisif, dan pola asuh cenderung otoriter. Dan terdapat hubungan yang baik antara pola asuh orangtua dan prestasi belajar siswa, dengan begitu memberikan pola asuh yang tepat kepada anak akan berpengaruh terhadap nilai dan prestasi belajar anak.
\end{abstract}

Kata kunci: Pola asuh orangtua, prestasi belajar

\begin{abstract}
The learning achievements of students are very Permasalahnya in influence by different parents parenting and will have an impact on the learning achievements of students. This research was conducted aiming to find out the relationship of parenting parents learning achievements against the grade IV SD Negeri Botolambat 03 Rods that add up to 24 students and 24 parents of students who became a source of research. The method of this research is a descriptive qualitative. Results of the study show that there are 3 student class IV category (very good), 13 categories (good), 8 categories (enough), and 0 category (less). The achievement of learning and parenting parents have different percentages. Parenting tend to be democratic, amounting to 12.5 (very good), 45 (good), 8.3 (enough); tends to be Permissive 16 (enough); tend to be Authoritarian 4 (good), 8.3 (enough). It could be inferred that there were three parenting parenting, parenting tend to be democratic, tend to permissive parenting, and parenting tend to be authoritarian. And there is a good relationship between the parenting parents and learning achievements of students, thus giving the proper parenting to the child will have an effect on the value of children's learning and achievement.
\end{abstract}

Keywords : Parenting parents, learning achievements 


\section{PENDAHULUAN}

Pendidikan merupakan hal yang sangat penting untuk meningkatkan kualitas sumber daya manusia (SDM) dalam menjalani keberlangsungan pembangunan suatu bangsa agar manusia memiliki pengetahuan, ketrampilan, dan di siplin dalam berbagai hal tentang pengetahuan dan agar secara aktif mengembangkan potensi yang ada didalam diri setiap manusia. pendidikan sangat di butuhkan oleh setiap negara agar bisa membangun suatu negara yang maju sehingga dengan adanya pendidikan yang sangat penting ini manusia-manusia modern akan bermunculan dan generasi millenial akan membawa banyak perubahan bagi suatu negara.

Di dalam pendidikan tidak hanya pendidikan saja yang berperan sebagai pencerdas Bangsa tetapi di dalam pendidikan juga termuat adanya pola asuh orang tua yang dimana perannya sangat besar bagi tumbuh kembangnya anak sekaligus behubungan dengan prestasi siswa karena orang tua adalah guru pertama bagi mereka sehingga pola asuh yang di berikan orang tua sangat berpengaruh terhadap prestasi belajar siswa.

UU Nomor 20 Tahun 2003 tentang Sistem Pendidikan Nasional, Pendidikan adalah usaha sadar dan terencana untuk mewujudkan suasana belajar dan proses pembelajaran agar peserta didik secara aktif mengembangkan potensi dirinya untuk memiliki kekuatan spritual keagamaan, pengendalian dirinya, kepribadian, kecerdasan, akhlak mulia, serta ketrampilan yang diperlukan dirinya, masyarakat bangsa dan negara.

Kamus Besar Bahasa Indonesia 1991: 232 (dalam Syah 2011: 10) mengatakan pendidikan ialah proses pengubahan sikap dan tata laku seseorang atau kelompok orang dalam usaha mendewasakan manusia melalui upaya pengajaran dan pelatihan. Pendidikan juga sangat penting bagi kelangsungan hidup manusia dengan adanya penddikan, manusia bisa menggali potensi yang dimilikinya dan mempunyai budi pekerti luhur.

Pendidikan merupakan pendidikan yang tidak membeda-bedakan anak satu dengan anak lainnya karena tujuan pendidikan adalah mencerdaskan anak bangsa agar dapat tumbuh dan berkembang sesuai usia perkembangannya. Pendidikan ialah urusan manusia hanya manusia yang memiliki pendidikan subyek dan obyek pendidkan adalah manusia, yang mendidik adalah manusia yang dididik juga manusia ( Soegeng, 2018: 63).

Pendidikan terbagi menjadi tiga jalur yaitu formal, nonformal, dan informal. Undang-Undang No. 20 Tahun 2003 dalam Kementrian Pendidikan dan Kebudayaan Tentang Sistem Pendidikan Nasional dalam Bab 1 Pasal 1 ayat 13 menyatakan bahwa pendidikan informal adalah jalur pendidikan keluarga dan lingkungan, karena mengingat lingkungan pendidikan pertama dan utama bagi anak adalah pendidkan keluarga. Interaksi awal yang terjadi antara anak dengan orangtua merupakan interaksi alami dan sudah menjadi kodrat yang digariskan oleh tuhan. Melalui interaksi dan pembiasaan sejak kecil dilakukan dengan orangtua sejak lahir hingga tumbuh dewasa, secara tidak langsung akan terekan kedalam memori secara alamiah pula hal tersebut nantinya akan menjadi pembelajaran dan pengetahuan oleh diri anak.

Orangtua merupakan bapak dan ibu yang senantiasa memdidik dan mengasuh anak sejak masih bayi hingga sampai dewasa, dan bertanggungjawab dalam suatu rumah tangga dalam kehidupan sehari-hari. Orangtua senantiasa membimbing dan mendidik anak untuk menuju kedewasaan, kelak saat dewasa anak bisa membahagiakan orangtua.

Pendidikan berlangsung seumur hidup manusia baik itu pendidikan formal maupun pendidikan informal yang tujuannya sama-sama membuat pikirannya lebih berkembang sekaligus mencerdaskan bagi anak dalam taraf sekolah. Jadi, pendidikan merupakan suatu upaya untuk mencerdaskan akal pikiran untuk meningkatkan kemampuan akademik yang secara aktif mengembangkan potensi dalam dirinya untuk mengaktifkan pribadi yang baik, berintelektual dan meningkatkan ketrampilan sekaligus menjadi pribadi yang baik.

Hurlock (1999) orang tua adalah orang dewasa yang membawa anak ke dewasa, terutama dalam masa perkembangan. Tugas orangtua melengkapi dan mempersiapkan anak menuju ke kedewasaan dengan memberikan bimbingan dan pengarahan yang dapat membantu anak dalam menjalani kehidupan. Dalam memberikan bimbingan dan pengarahan pada anak akan berbeda pada masing-masing orang tua karena setiap keluarga memiliki kondisi - kondisi 
tertentu yang berbeda corak dan sifatnya antara keluarga yang satu dengan keluarga yang lain. Meskipun demekian pada hakekatnya, setiap orangtua mempunyai tanggungjawab tersebut ditujukan dalam penataan perilaku anak yang disebut dengan pola asuh (Havighurst, dalam Hurlock, 1999).

Orangtua sebagai penyelenggara pendidikan utama jelas berpengaruh terhadap perkembangan anak sekaligus menambah ilmu pengetahuan karena orang tua dianggap mempunyai banyak pengetahuan yang akan mengajarkan berbagai hal dalam kehidupan anak. disini pentingnya orangtua untuk mengajari ilmu pengetahuan agar prestasi anak bisa tercapai secara optimal. Orangtua akan secara terus menerus memberikan yang terbaik kepada anak agar apa yang diinginkan orangtua terhadap anak bisa tercapai dan apa yang menjadi keinginan anak bisa terwujud melalui pembelajaran keluarga.

Orangtua merupakan bapak dan ibu yang senantiasa memdidik dan mengasuh anak sejak masih bayi hingga sampai dewasa, dan bertanggungjawab dalam suatu rumah tangga dalam kehidupan sehari-hari. Orangtua senantiasa membimbing dan mendidik anak untuk menuju kedewasaan, kelak saat dewasa anak bisa membahagiakan orangtua.

Orangtua dalam hal ini adalah keluarga merupakan suatu lembaga yang dimana selalau mengajarkan anak berbagai hal seperti, belajar, sopan santun, dan berinteraksi sosial denagn orang lain. Peran orangtua sangat mempengaruhi keberhasilan prestasi belajar anak karena orang tua selalu mendidik anaknya setelah lingkungan sekolah. Keluarga sangat kuat pengaruhnya untuk merubah pola pikir anaknya sehingga anak akan mempunyai sifat baik atau tidaknya tergantung pola asuh yang diberikan oleh keluarga. Tetapi semua keluarga menginginkan potensi yang ada dalam diri anak tapi, keluarga tidak serta merta membantu memunculkan potensinya dalam diri anaknya karena orang tua terlalu sibuk dengan urusan pekerjaannya yang akan membuat potensi dalam diri anak tidak muncul atau tidak berkembang.

Keluarga memiliki peran sebagai media sosialisasi pertama bagi anak. Peran inilah yang membuat orangtua memiliki rasa tanggung jawab tehadap perkembangan anak. Di dalam kehidupan keluarga anak mulai di perkenalkan sopan santun dari mulai bahasa,tutur kata dan juga perilaku.
Dari orangtualah anak akan menjadi seperti apa tergantung dari pola asuh orang tua yang diberikan kepada anak. Pola asuh yang diberikan orang tua terhadap anak akan mempengaruhi perkembangan intelektual yang ada dalam diri anak.

Tugas orangtua tidak hanya sekedar memberi nafkah atau uang jajan kepada anak tetapi juga memberikan asuhanasuhan dalam diri anak agar potensi yang ada dalam diri anak tumbuh dan berkembang, Sehingga anak akan mudah mencari prestasi belajarnya karena adanya polaasuh yang diberikan orang tua terhadap anak. Orang tua selain bekerja untuk keluarga juga membimbing anak-anak agar menjadi siswa yang berprestasi di sekolah karena prestasi belajar anak dipengaruhi oleh pola asuh orang tua, apabila anak tidak mendapatkan pola asuh yang tepat atau tidak mendapatkan pola asuh orang tua sama sekali maka besar kemungkinan anak tidak mendapat prestasi belajar di sekolah.

Djamarah (2014: 18) keluarga adalah sebagai sebuah institusi yang terbentuk karena ikatan perkawinan. Di dalamnya hidup bersama pasangan suami istri secara sah karena pernikahan. Di dalam keluarga terdapat keluarga besar dan keluarga inti. Keluarga adalah kelompok primer yang paling penting dalam masyarakat, sedangkan dalam dimensi hubungan sosial, keluarga merupakan suatukesatuan yang diikat oleh adanya saling berhubungan atau interaksi dan saling mempengaruhi antara satu dengan yang lainnya.

Soeleman 1998: 17 (dalam Shochib) dalam pengertian psikologis, keluarga adalah sekumpulan orang yang hidup bersama dalam tempat tinggal bersama dan masing-masing anggota merasakan adanya pertautan batin sehingga terjadi saling mempengaruhi, saling memperhatikan, dan saling menyerahkan diri. Dalam keluarga inti terdiri ayah, ibu, dan anak yang dalam kehidupan sehari-hari selalu bersama di tempat tinggal yang sama.

Djamarah (2014:18) keluarga adalah sebagai sebuah institusi yang terbentuk karena ikatan perkawinan. Di dalamnya hidup bersama pasangan suami-istri secara sah karena pernikahan. Di dalam keluarga terdapat keluarga besar dan keluarga inti. Keluarga adalah kelompok primer yang paling penting dalam masyarakat. Sedangkan dalam dimensi hubungan sosial, keluarga merupakan suatu kesatuan yang diikat oleh adanya saling berhubungan atau interaksi dan saling mempengaruhi antara satu dengan yang lainnya. 
Penelitian yang dilakukan oleh Dwi Yuli Setiasi (2015) menunjukan bahwa terdapat hubungan positif dan signifikan antara pola asuh orangtua dengan prestasi belajar siswa yang telah dibuktikan secara statistik dan diperkuat oleh hasil pengkategorian kelas interval. Karena semakin baik pola asuh orangtua terhadap siswa maka akan diikuti oleh peningkatan prestasi belajar siswa. Pendapat yang serupa juga di kemukakan oleh

Keluarga memiliki peran sebagai media sosialisasi pertama bagi anak. peran inilah yang membuat orangtua memiliki rasa tanggung jawab terhadap perkembangan anak. di dalam kehidupan keluarga anak mulai di perkenalkan sopan santun dari mulai bahasa, tutur kata, dan juga perilaku. Dari orangtualah anak akan menjadi seperti apa tergantung dari pola asuh orangtua yang diberikan kepada anak. pola asuh yang diberikan orangtua terhadap anak akan mempengaruhi perkembangan intelektual yang ada dalam diri anak.

Pola asuh sendiri merupakan pola yang bersifat konsisten dari waktu ke waktu, pola perilaku ini dapat di rasakan oleh anak dan bisa memberi efek negatif maupun positif. Orang tua sebagai pendidikan utama memiliki pola tersendiri dalam mengasuh dan membimbing anak. pola asuh orang tua merupakan gambaran tentang sikap dan perilaku orang tua dan anak dalam berinteraksi, komunikasi selama mengadakan kegiatan pengasuhan.

Bentuk-bentuk pola asuh orang tua mempengaruhi pembentukan kepribadian anak setelah ia menjadi dewasa. Hal ini di karenakan ciri-ciri dan unsur-unsur watak seorang individu dewasa sebenarnya jauh sebelumnya benih-benih sudah di tanamkan kedalam jiwa seorang individu sejak sangan awal, yaitu pada masa ia masih anak-anak.

Dalam melakukan penelitian peneliti ingin mengetahui pola asuh yang diberikan orangtua siswa dan hubungan pola asuh orangtua dengan prestasi belajar siswa kelas IV SD Negeri Botolambat 03 Batang.

\section{METODE}

Penelitian ini merupakan penelitian deskriptif kualitatif dengan pendekatan deskriptif persentase. Populasi dalam penelitian ini adalah seluruh siswa kelas IV SD Negeri Botolambat 03 Batang, seluruh orangtua siswa, guru kelas IV, dan kepala sekolah.

Pengambilan data dilakukan secara purposive dengan sumber data yaitu kepala sekolah, guru kelas IV, siswa kelas IV, dan orangtua siswa. Teknik pengumpulan data dalam penelitian ini adalah observasi, wawancara, angket/kuesioner, dan dokumentasi. Observasi dalam penelitian ini menggunakan observasi terstruktur karena peneliti sebelumnya sudah mengetahui permasalahan yang akan peneliti lakukan, observasi dilakukan untuk mengetahui pola asuh orangtua terhadap prestasi belajar siswa. Wawancara yang dilakukan peneliti adalah wawancara terstruktur dimana peneliti menggunakan pedoman wawancara yang telah tersusun secara sistematis dan lengkap untuk pengumpulan data. Pedoman wawancara digunakan hanya berupa garis-garis besar permasalahan yang akan ditanyakan, dalam penelitian ini yang menjadi narasumber wawancara yaitu guru kelas IV, semua siswa kelas IV, kepala sekolah, dan orangtua siswa yang berjumlah 24 orang.

Dalam penelitian peneliti tidak hanya menggunakan pedoman wawancara untuk pengumpulan data, melainkan menggunakan alat bantu tambahan seperti perekam suara, video yang dapat membantu proses wawancara kepada narasumber. Dalam penelitian ini yang menjadi narasumber wawancara yaitu guru kelas IV, kepala sekolah, dan orangtua siswa yang berjumlah 24 orang, sehingga jumlah yang diwawancarai oleh peneliti adalah 26 orang.

Sedangkan angket digunakan untuk mengumpulkan informasi yang memungkinkan analisis mempelajari sikapsikap, keyakinan, perilaku, dan karakteristik beberapa orang utama dalam organisasi yang bisa berpengaruh oleh sistem yang disajikan atau oleh sistem yang sudah ada. Angket digunakan adalah jenis angket tertutup/berstruktur yaitu responden diberi sejumlah pertanyaan-pertanyaan mengenai pola asuh orangtua. Angket ini diberikan kepada siswa kelas IV dan orangtua siswa kelas IV untuk menganalisis pola asuh apa yang diberikan oleh orangtua terhadap anak terhadap prestasi belajar anak.

Dokumentasi yang digunakan pada penelitian ini adalah video, rekaman, dan foto yang digunakan untuk melengkapi data yang diperoleh dari observasi, wawancara, dan angket. Dalam dokumentasi peneliti mendokumentasikan orangtua siswa, siswa kelas IV, guru kelas IV, kepala sekolah dan hal-hal yang ditemui oleh peneliti. 


\section{HASIL DAN PEMBAHASA}

Dalam penelitian ini menganalisis tentang pola asuh yang diberikan orangtua terhadap anak dan hubungan pola asuh orangtua terhadap prestasi belajar siswa kelas IV. Untuk melihat hasil pola asuh orangtua peneliti menganalisis menggunakan angket dan wawancara yang dibagikan kepada seluruh siswa kelas IV sebanyak 24 siswa. Dari hasil angket yang diperoleh peneliti untuk melakukan analisis pola asuh orangtua terhadap prestasi belajar pada siswa kelas IV SD Negeri Botolambat 03 Batang, yang sebelumnya sudah dianalisis menjadi empat pola asuh yang sebelumya ada lima belas pola asuh orangtua keempat pola asuh tersebut ialah pola asuh Demokratis, pola asuh Permisif, pola asuh Otoriter, dan pola asuh Penelantaran. Hasil analisis akan menunjukan ada berapa orangtua siswa yang menerapkan pola asuh demokratis, permisif, otoriter, dan penelantaran. Setelah di analisis berdasarkan hasil yang terbanyak maka akan di tentukan jenis pola asuh.

Hasil ini didapat setelah peneliti melakukan analisis dari jawaban seluruh siswa melalui angket yang telah dibagikan kepada siswa kelas IV. Setelah di analisis dan di hitung berdasarkan hasil yang terbanyak dari setiap pola asuh orangtua terhadap siswa, maka dapat dilihat data dan persentase dari setiap pola asuh yang diterapkan orangtua siswa dalam tabel berikut.

Tabel 1.Hasil Persentase Jenis Pola Asuh Orangtua

\begin{tabular}{lcc}
\hline \multicolumn{1}{c}{ Jenis Pola Asuh Orangtua } & Hasil Perolehan Siswa & Persentase (\%) \\
\hline Cenderung Demokratis & 16 & 66 \\
\hline Cenderung Permisif & 5 & 20 \\
\hline Cenderung Otoriter & 3 & 12,5 \\
\hline Cenderung Penelantaran & - & - \\
\hline
\end{tabular}

Pola asuh yang cenderung Demokratis diterapkan oleh 16 orangtua terhadap siswa kelas IV, sehingga perolehan persentase adalah sebanyak $66 \%$. Pola asuh cenderung Permisif diterapkan oleh 5 orangtua terhadap siswa kelas IV dengan perolehan persentase sebanyak 20\%. Sedangkan pola asuh cenderung Otoriter diterapkan oleh 3 orangtua siswa kelas IV dengan perolehan persentase sebanyak $12,5 \%$ dan untuk pola asuh cenderung Penelantaran tidak diterapkan oleh orangtua siswa kelas IV karena setiap orangtua memberikan pola asuhan terhadap anak dengan berbagai jenis pola asuh sehingga tidak ada anak yang tidak mendapatkan pola asuh dari orangtuanya dan anak tidak ada anak yang mendapatkan pola aasuh jenis penelantaran pada saat penelitian dilakukan.

Dari hasil analisis bahwa orangtua siswa kelas IV SD Negeri Botolambat 03 Batang lebih banyak menerapkan pola asuh Demoktaris dengan demikian bahwa pola asuh Demokratis lebih dominan menyusul dengan pola asuh Permisif dan pola asuh Otoriter.

Berdasarkan hasil dari penghitungan tentang prestasi belajar siswa kelas IV SD Negeri Botolambat 03 batang yang diperoleh dari nilai Ulangan Tengah Semester tema 1 dan tema 2, mata pelajaran (Bahasa Indonesia, IPA, IPS, PPKn, SBdP)

Selanjutnya peneliti menganalisis prestasi belajar siswa kelas IV SD Negeri Botolambat 03 Batang, dengan hasil seperti pada tabel berikut:

Tabel 2. Persentase Belajar Siswa Kelas IV SD Negeri Botolambat 03 Batang

\begin{tabular}{lcc}
\hline Kategori Prestasi & Jumlah perolehan siswa & $\begin{array}{c}\text { Persentase } \\
(\%)\end{array}$ \\
\hline Sangat Baik & 3 & 12,5 \\
\hline Baik & 13 & 54 \\
\hline Cukup & 8 & 33 \\
\hline Kurang & 0 & 0 \\
\hline
\end{tabular}

Dari hasil penelitian dapat diperoleh bahwa siswa yang mendapatkan prestasi
Sangat Baik berjumlah 3 siswa denagn persentase $12,5 \%$, siswa yang 
mendapatkan prestasi Baik berjumlah 13 siswa dengan persentse $54 \%$, dan siswa yang mendapatkan nilai Cukup berjumlah 8 siswa dengan persentase 33\%. Denagn demikian dapat dikatakan bahwa lebih dari $50 \%$ siswa kelas IV SD Negeri Botolambat 03 Batang mempunyai prestasi yang Baik dan selebihnya mempunyai prestasi yang Sangat Baik dan Cukup.

Dengan demikian dapat dikatakan bahwa lebih dari $54 \%$ siswa kelas IV SD Negeri Botolambat 03 Batang mempunyai prestasi belajar Baik dan selebihnya mempunyai prestasi belajar Sangat Baik dan Cukup.

Prestasi adalah hasil dari suatu kegiatan yang telah dikerjakan, diciptakan, baik secara individual maupun kelompok
(Hamdani 2011: 137), prestasi tidak akan pernah muncul apabila seseorang tidak melakukan kegiatan belajar.

Dari banyaknya prestasi belajar siswa kelas IV SD Negeri Botolambat 03 Batang peneliti mimilah siswa-siswi yang mendapat nilai tertinggi sebanyak 5 siswa yang menurut peneliti dan guru kelas IV Bapak Fadelun, S.Pd selaku guru kelas IV, siswa-siswi tersebut berprestasi atau menonjol dalam hal prestasi belajar nilai diambil dari Ulangan Tengah Semester tema 1 dan tema 2 serta mata pelajaran lainnya seperti, Bahasa Indonesia, PPKn, IPA, IPS, dan SBdP. Nilai tersebut digabungkan dan mencari rata-rata yang tertinggi dan nilai tertinggi dari 24 siswa lainnya dalam prestasi belajar seperti tabel berikut:

Tabel 3. Nilai Tertinggi Siswa Kelas IV SD Negeri Botolambat 03 Batang

\begin{tabular}{lcccc}
\hline \multirow{2}{*}{ Nama Siswa } & \multicolumn{4}{c}{ Prestasi Belajar Siswa } \\
\cline { 2 - 5 } & $\begin{array}{c}\text { Nilai UTS } \\
\text { Tema 1 }\end{array}$ & $\begin{array}{c}\text { Nilai UTS } \\
\text { Tema 2 }\end{array}$ & Nilai & Rata-rata \\
\hline Reza & 89 & 91 & 622 & 88 \\
\hline Ikrima & 90 & 89 & 612 & 87 \\
\hline Sukirjo & 84 & 79 & 566 & 80 \\
\hline Sirojul & 81 & 83 & 546 & 78 \\
\hline Aini & 84 & 80 & 522 & 74 \\
\hline
\end{tabular}

Dari kelima siswa-siswi yang mempunyai nilai tertinggi dalam prestasi belajar semua itu tidak lepas dari peran orangtua yang selalu membimbing dan mendidik anak agar menjadi berprestasi dan pola asuh ikut serta dalam keberhasilan anak dalam membimbing dan mendidik anak untuk berprestasi, sehingga apa yang di lakukan orangtua terhadap anak akan membentuk dalam diri anak baik dari segi kognitif, psikomotorik, dan afektif semua itu hanya agar anak mendapat nilai yang baik dan prestasi yang baik disekolah.

Untuk melihat berapa banyak siswa yang mendapatkan pola asuh orangtua cenderung demokratis, pola asuh cenderung permisif, pola asuh cenderung otoriter, dan pola asuh cenderung penelantaran. Hasil didapat setelah peneliti melakukan analisis dari jawaban siswa menggunakan angket yang telah dibagikan kepada siswa kelas IV dan di hitung maka dapat dilihat bahwa pola asuh orangtua cenderung demokratis memiliki persentase sebanyak $66 \%$, pola asuh orangtua cenderung permisif memiliki persentase sebanyak $20 \%$, pola asuh orangtua cenderung otoriter memiliki persentase sebanyak $12,5 \%$ dan $0 \%$ untuk pola asuh orangtua cenderung penelantaran.

Hal itu disebebkan karena para orangtua siswa memberikan pola asuh terhadap anak dengan berbagai pola asuh yang ada dan agar siswa yang orangtua didik mendapatkan prestasi yang baik, sehingga tidak ada pola asuh cenderung penelantaran. Dengan demikian bahwa pola asuh cenderung demokratis lebig dominan daripada pola asuh cenderung permisif, pola asuh cenderung otoriter.

Berdasarkan penelitian terhadap pola asuh orangtua dan prestasi belajar yang telah peneliti lakukan kepada siswa kelas IV SD Negeri Botolambat 03 Batang, maka peneliti menghitung pola asuh orangtua dan prestasi belajar yang disajikan dalam tabel berikut: 
Tabel 4. Hasil Pola Asuh Orangtua dan prestasi Belajar Siswa Kelas IV SD Negeri Botolambat 03 Batang

\begin{tabular}{lccccccccc}
\hline \multirow{2}{*}{ Pola Asuh Orangtua } & \multicolumn{7}{c}{ Prestasi Belajar Siswa Kelas IV } \\
& \multicolumn{1}{c}{$\begin{array}{c}\text { Sangat Baik } \\
\text { (A) }\end{array}$} & \multicolumn{2}{c}{$\begin{array}{c}\text { Baik } \\
\text { (B) }\end{array}$} & \multicolumn{2}{c}{$\begin{array}{c}\text { Cukup } \\
\text { (C) }\end{array}$} & \multicolumn{2}{c}{$\begin{array}{c}\text { Kurang } \\
\text { (D) }\end{array}$} \\
\cline { 2 - 11 } & $\mathrm{N}$ & $\%$ & $\mathrm{~N}$ & $\%$ & $\mathrm{~N}$ & $\%$ & $\mathrm{~N}$ & $\%$ \\
\hline Cenderung Demokratis & 3 & 12,5 & 11 & 45 & 2 & 8,3 & - & - \\
\hline Cenderung Permisif & - & - & - & - & 4 & 16 & - & - \\
\hline $\begin{array}{l}\text { Cenderung } \\
\text { Otoriter }\end{array}$ & - & - & 1 & 4 & 2 & 8,3 & - & - \\
\hline Cenderung Penelantaran & - & - & - & - & - & - & - & - \\
\hline
\end{tabular}

Dari hasil analisis dan perhitungan menggunakan persentase maka pola asuh orangtua dan prestasi belajar siswa kelas IV SD Negeri Botolambat 03 Batang didapat bahwa pola asuh cenderung demokratis diterapkan oleh 3 siswa yang mendapkan prestasi Sangat Baik dengan memperoleh persentase sebanyak $12,5 \%$, pola asuh cenderung demokratis juga diterapkan oleh 11 siswa yang mendapatkan prestasi Baik dengan memperoleh persentase sebanyak $45 \%$, dan pola asuh cenderung demokratis juga diterapkan oleh 2 siswa yang mendapatkan prestasi Cukup dengan memperoleh persentase sebanyak $8,3 \%$; pola asuh cenderung permisif diterapka oleh 4 siswa yang mendapatkan prestasi Cukup dengan memperoleh persentase sebanyak $16 \%$.

Pola asuh cenderung otoriter diterapkan oleh 1 siswa yang mendapatkan prestasi Baik dengan memperoleh persentase sebanyak $4 \%$ dan juga diterapkan oleh 2 siswa yang mendapatkan prestasi Cukup dengan memperoleh persentase sebanyak $8,3 \%$. Pola asuh cenderung penelantaran diterapkan oleh 0 siswa sehingga tidak memperoleh kategori dan persentase. Dari hasil penghitungan dan analisis bahwa orangtua menerapkan tiga pola asuh yaitu pola asuh orangtua cenderung demokratis, pola asuh orangtua cenderung permisif, dan pola asuh orangtua cenderung otoriter.

Berdasarkan hasil pola asuh orangtua dan prestasi belajar siswa dapat dikatakan bahwa pola asuh yang di terapkan oleh orangtua siswa berhubungan atau berpengaruh terhadap prestasi belajar siswa.

Berdasarkan hasil pola asuh orangtua dan prestasi belajar siswa peneliti menentukan nilai-nilai dan rata-rata tertinggi dari 5 siswa/siswi yang mempunyai nilai dan rata-rata tertinggi berdasarkan dari keseluruhan nilai Ulangan Tengah Semester dan mata pelajaran lainnya seperti, Bahasa Indonesia, PPKn, IPA, IPS, dan SBdP yang ditentukan secara purposive dengan pola asuh orangtua pada tabel sebagai berikut:

Tabel 5. Hasil Prestasi Belajar Siswa Kelas IV Dengan Pola Asuh Orangtua

\begin{tabular}{|c|c|c|c|c|}
\hline \multirow{2}{*}{ Nama Siswa } & \multicolumn{2}{|c|}{ Prestasi Belajar Siswa } & \multirow{2}{*}{$\begin{array}{c}\text { Nama } \\
\text { Orangtua }\end{array}$} & \multirow{2}{*}{$\begin{array}{c}\text { Pola Asuh } \\
\text { Orangtua }\end{array}$} \\
\hline & Nilai & Rata-rata & & \\
\hline Reza Nafid Amanulloh & 622 & 88 & Muslimah & Demokratis \\
\hline Ikrima Maydinta Azzahra & 612 & 87 & Zaenal Arifin & Demokratis \\
\hline Sukirjo & 566 & 80 & Yahya & Demokratis \\
\hline Sirojul Munir M.R & 546 & 78 & Munawir & Demokratis \\
\hline Aini Ayu Nasikha & 522 & 74 & Kasmirah & Demokratis \\
\hline
\end{tabular}

Dalam kaitannya prestasi belajar anak orangtua mendukung dan bekerjasama agar anaknya mendapat prestasi di sekolah dengan membelikan buku-buku pelajaran dan peralatan lainnya yang mendukung proses belajar anak. Jika anak dalam belajar kurang memahami atau kesulitan dalam belajar maka orangtua memberikan solusi agar anak tidak kesulitan dalam belajar, didalam keluarga jika anak tidak mematuhi aturan keluarga makan orangtua akan menegurnya.

Orangtua didalam keluarga menerapkan sikap tergas dan disiplin dan anak harus patuh terhadap perintah dan larangan. Dalam pola asuh demokratis ini orangtua tidak hanya mendidik anak tetapi membing anak jika anak salah dalam perbuatnnya, orangtua senantiasa mendidik anak dengan penuh kasih sayang sehingga 
orangtua bisa mempersiapkan anak dimasa mendatang.

Dari hasil analisis penerapan pola asuh orangtua terhadap anak maka Pola asuh cenderung demokratis dimiliki sebanyak $66 \%$ orangtua siswa dalam mendidik dan membimbing anak dalam prestasi belajar. Dengan adanya pola asuh demokratis yang diterapkan oleh orangtua terhadap anak akan menyebabkan perasaan nyaman dan menjadikan suasana dalam keluarga menjadi harmonis, orangtua lebih perhatian terhadap anak, dan berkomunikasi secara bebas namun harus diperhatikan norma-norma yang ada didalam keluarga serta aturan-aturan yang bersifat kekeluargaan yang dimana suatu keputusan harus diputuskan bersama-sama. Bahwa pola asuh demokratis selalu mendahulukan kepentingan bersama diatas kepentingan individu anak, Djamarah (2014: 60).

Pola asuh cenderung permisif di terapkan oleh $20 \%$ orang tua siswa, pola asuh cenderung permisif orangtua lebih bebas menerima masukan atau pendapat dari anak baik positif maupun negatif, orangtua tidak pernah melarang anak melakukan hal-hal yang diinginkan, orangtua tidak merasa khawatir ketika anak bermain jauh dari rumah, serta orang tua menuruti kemauan anak tanpa memikirkan lebih jauh lagi tentang anak. pola asuh cenderung permisif ini memberikan kebebasan kepada anak untuk mengekpresikan dari setiap perbuatan dan tindakan tanpa adanya norma-norma yang ada.

Orang tua tidak pernah menasehati atau memarahi anak ketika anak berbuat kesalahan karena orangtua merasa canggung untuk memarahi atau menasehati. Pola asuh cenderung permisif tidak berdasarkan aturan-aturan kebebasan memilih terbuka bagi anak dengan sedikit campur tangan orangtua, menginginkan seluruh anak berpartisipasi tanpa memaksa atau menuntut kewenangan yang dimilikinya.

Pola asuh cenderung otoriter diterapkan oleh $12,5 \%$ orangtua siswa, pola asuh cenderung otoriter akan menolak dari setiap bentuk emosional anak dan kemauan anak ditolak. Kurangnya memberikan perhatian dan kasih sayang terhadap anak serta mengengkang dari setiap tindakan anak tanpa adanya toleransi, dan kurangnya waktu luang untuk berkomunikasi dengan anak. hal ini disebabkan karena kondisi orangtua yang emosional dan tempramental yang tidak bisa mengendalikan kontrol emosi diri. Orangtua yang kaku terhadap lingkungan keluarga berdampak buruk bagi anak dan keluarga karena sifat dari emosionalnya yang buruk sehingga tidak bisa memcahkan masalah dengan pemikiran yang jernih.

Hal tersebut juga di sampaikan oleh Djamarah (2014: 60) mengemukakan bahwa orangtua dengan pola asuh cenderung otoriter sebagai pengendali atau pengawas (controiler) selalu memaksa kehendak kepada anak, tidak mudah terbuka terhadap anak, sangat sulit menerima saran dan cenderung memakasa kehendak dalam perbedaan, terlalu percaya diri sehingga menutup katup musyawarah.

\section{SIMPULAN DAN SARAN}

Berdasarkan temuan hasil penelitian yang di lakukan oleh siswa kelas IV SD Negeri Botolambat 03 Batang pada bab IV dapat disimpulkan bahwa:

Peneliti menemukan tiga pola asuh orangtua yang sebelumnya ada empat pola asuh orangtua yang menjadi fokus penelitian yaitu pola asuh cenderung demokratis, pola asuh cenderung permisif, dan pola asuh cenderung otoriter. Dari ketiga pola asuh tersebut pola asuh demokratislah yang lebih banyak diterapkan oleh orangtua siswa kelas IV yaitu sebanyak 16 siswa, disusul oleh pola asuh cenderung permisif sebanyak 5 siswa, pola asuh cenderung otoriter 3 siswa dan tidak menemukan adanya pola asuh penelantaran.

Terdapat hubungan yang baik antara pola asuh orangtua dengan prestasi belajar siswa. Karena orangtua yang memberikan pola asuh yang baik kepada anak maka akan mempengaruhi prestasi belajar siswa. Dengan begitu memberikan pola pola asuh yang pas kepada anak maka akan berpengaruh terhadap nilai dan prestasi belajar anak.

Berdasarkan temuan hasil penelitian yang dilakukan di SD Negeri Botolambat 03 Batang pada siswa kelas IV, maka peneliti menyampaikan saran-saran sebagai berikut. Bagi guru, diharapkan mampu menjalin komunikasi dengan siswa dan orangtua dengan baik agar mampu menciptakan suasana belajar yang menyenangkan agar dapat meningkatkan prestasi belajar siswa, guru harus memperhatikan perkembangan prestasi belajar siswa terutama bagi siswa yang mempunyai prestasi rendah. Bagi siswa, agar mempunyai semangat belajar yang tinggi sekaligus dapat meraih prestasi yang tinggi dan bisa menggapai cita-cita yang diinginkan. Bagi orangtua, diharapkan 
bisa memberikan pola asuh yang tepat bagi anak dan mendukung anak untuk melakukan kegiatan yang positif, dan memberikan perhatian yang lebih agar mampu meningkatkan prestasi belajarnya. Bagi sekolah, diharapkan menjalin komunikasi dengan para guru-guru untuk bisa meningkatkan prestasi belajar siswa agar siswa-siswa ini bisa meraih masa depan yang diharapkannya.

\section{DAFTAR PUSTAKA}

Depdiknas, 2003. Undang-Undang Republik Indonesia Nomor 20 Tahun 2003 tentang Sistem Pendidikan Nasional. Dikutip 7 November 2018 pukul 20:15 WIB dari https://kelembagaan.ristekdikti.go id.

Djamarah, Syaiful Bahri. 2014. Pola Asuh Orangtua dan Komunikasi dalam Keluarga. Jakarta: Rineka Cipta.

Hamdani. 2011. Strategi Belajar Mengajar. Bandung: Pustaka Setia.

Hurlock,B Elizabeth. 1993. Perkembangan Anak Jilid 2 edisi 6. Jakarta: Penerbit Erlangga.

Setiasih, Yuli, Dwi, 2015. Hubungan Pola Asuh OrangTua Dengan Prestasi Belajar Siswa Kelas V SD SeGugus Wonokerto Turi Sleman. Sleman: Universitas PGRI Yogyakarta.

Shochib, Moh. 1998. Pola Asuh Orang Tua Dalam Membantu Anak Mengembangkan Disiplin Diri. Jakarta: Rineka Cipta.

Soegeng. A.Y. 2018. Filsafat Pendidikan. Yogyakarta: Magnum.

Moleong, Lexy J. 2007. Metode Penelitian Kualitatif . Edisi Revisi. Bandung: PT.Remaja RosdaKarya.

Syah, Muhibbin. 2011. Psikologi Pendidikan. Bandung: PT Remaja Rosdakarya.

Sugiyono. 2017. Metode Penelitian Pendidikan (Pendekatan Kuantitatif, Kualitatif, dan $R \& D)$. Bandung: Alfabeta. 